\title{
Consensus
}

Volume 21

Issue 1 Women and Men in Theological Education:

Article 18

Exploring the Present, Creating the Future

5-1-1995

\section{Israel and the politics of land: a theological case study}

John H. C. Neeb

Follow this and additional works at: http://scholars.wlu.ca/consensus

\section{Recommended Citation}

Neeb, John H. C. (1995) "Israel and the politics of land: a theological case study," Consensus: Vol. 21 : Iss. 1 , Article 18.

Available at: http://scholars.wlu.ca/consensus/vol21/iss1/18

This Book Reviews is brought to you for free and open access by Scholars Commons @ Laurier. It has been accepted for inclusion in Consensus by an authorized editor of Scholars Commons @ Laurier. For more information, please contact scholarscommons@wlu.ca. 
whether the Jesus we have found is the Jesus we wanted to find. "The last temptation is to create Jesus in our own image, to marshal the facts to support preconceived convictions" (p. 5). It is this temptation which has led the Jesus Seminar as its final general rule: Beware of finding a Jesus entirely congenial to you. This is a message each of us who preaches and teaches in the church needs to hear. I think that this book is a necessity in the library of every pastor.

Carol J. Schlueter

Waterloo Lutheran Seminary

\section{Israel and the Politics of Land: A Theological Case Study \\ W. Eugene March}

Foreword by Walter Brueggemann

Louisville: Westminster/John Knox Press, 1994

112 pp. $\$ 12.99$ U.S. paper

This timely book reached my desk fresh from the publisher one week before leaving on a Study Tour to Israel and the Occupied Territories. The author takes the reader on a fascinating historical and theological journey beginning with Abraham and Sarah and ending with the dramatic Israeli-Palestinian Liberation Organization peace accord signed in September, 1993.

The author's thesis is that "[L]and is best understood as a divine loan intended for responsible (righteous and just) use. Human communities require land, but they can never claim full ownership and are ever to be judged by how they exercise dominion over the land" (p. xi).

"People and Land: Many Faces, Many Voices" heads the engaging first chapter sketching the profiles of several true-to-life Arabs and Jews who daily wend their way through the Damascus and Jaffa gates.

Chapter 2, "The Realities of History: People, Power, and Palestine", sketches the history of the land from Roman times, ending with the Arafat and Rabin handshake in Washington, D.C. on September 13, 1993. March evoked shivering chills in this reviewer at the memory of September, 1982, when Lebanese Christian militiamen entered two Palestinian refugee camps, Sabra and Shatila, under protective cover of Israeli army units, and mercilessly slaughtered hundreds of people, mostly women and children.

Chapter 3, "God and Earth-keeping: Biblical Perspectives on Land", presents a standard from which to assess earth-keeping, i.e. "[T]he success or failure of every attempt at dominion can be measured against the Bible's call for righteousness, for love, for mercy, for justice" (p. 47).

In Chapter 4, "God's Way and Israel: Theological Reflections on a Particular Land", March meets his greatest challenge. He claims that "[A]ny 
rights held by biblical Israel do not belong to modern Israel" (p. 67). On the other hand he cautions that Christians cannot assume to own the biblical heritage all by themselves.

Chapter 5, "A Guiding Vision: A Call to Be Earth-keepers" concludes with March articulating a vision which sounds like strains from Isaiah 9 or 11. "Earth, God's good land, has been placed in human hands by a loving creator who desires that all live in harmony and prosperity-that is, in shalom, peace" (p. 84).

March has made a serious attempt to address the thorny issue of land in an incarnational way. He describes his method of analysis as threefold, "historical reality, biblical accounts and imagery, and theological constructs" (p. 95). The historical portions are superb; biblical material is handled sensitively. He falls short, however, in applying his thesis to injustices against Palestinians. The United States has pride of place in his list of "wealthiest industrialized nations" who "even more urgently" have the mandate to care for the land (p. 87). Does the greatest wealth imply the greatest power in making decisions about "God's land"? Also, one wearies of his constant reference to "Reformed Christians" (e.g. pp. 79, 80, 92, 94, 95).

March has written a remarkable little book. For anyone wanting to get acquainted with the inexorable complexities haunting that narrow strip of land soaked in so much human blood, this book is an excellent entry point.

John H. C. Neeb

Waterloo Lutheran Seminary

\section{Born of a Woman: A Bishop Rethinks the Birth of Jesus \\ John Shelby Spong}

San Francisco: Harper, 1992

$245 \mathrm{pp}$.

As its title suggests, Born of a Woman examines the New Testament narratives describing the birth of Jesus. Moreover, implicit in the title is the author's essential claim that Jesus' birth was originally conceived to be as normal a function of biology as any other human birth. Bishop John Shelby Spong of Newark argues that the development of the Virgin Birth dogma was motivated by the need to maintain the status quo of a patriarchal church, and has contributed substantially to the oppression of women.

From cover to cover Spong articulates his case most persuasively. He is a formidable scholar and provocative writer. For example, he caricatures the intercessions of Mary, for which many devout Christians invoke her name, 